\title{
MEDUSA NAVICULA.
}

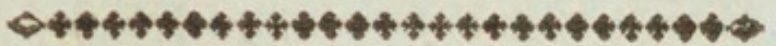

\section{CHARACTER GENERICUS.}

Corpus gelatinofum, orbiculatum, depreffum. Os fubtus, centrale.

$$
\text { Lin. Syft. Nat. p. } 1096 .
$$

CHARACTER SPECIFICUS, छc.

MEDUSA ovalis cærulea, oblique criftata, crifta bipartita, fubtus tentaculis numerofiffimis.

HOLOTHURIA fpirans.

$$
\begin{aligned}
& \text { Lin. Syft. Nat. Gmel. p. } 3143 . \\
& \text { Forfk. Fn. As. Arab. p. 104. n. } 15 .
\end{aligned}
$$

Pulcherrimum animal in tabula depictum in mari Mediterraneo frequentiffime confpicitur, fuper aquas, more Medufæ Velellæ, cui admodum affine eft, velificans. Veram ejus magnitudinem cernere eft in tabula. 
T HE

\section{SKIFF MEDUSA.}

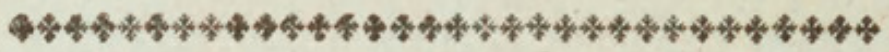

\section{GENERIC CHARACTER.}

Body gelatinous, orbicular, commonly depreffed. Mouth central, beneath.

\section{SPECIFIC CHARACTER.}

OVAL BLUE MEDUSA, with oblique, divided creft, and very numerous tentacula beneath.

The beautiful animal here figured is very frequently obferved in the Mediterranean fea, failing on the furface of the water in the manner of the Medufa Velella, to which it is extremely nearly allied: it is reprefented in its natural fize. 


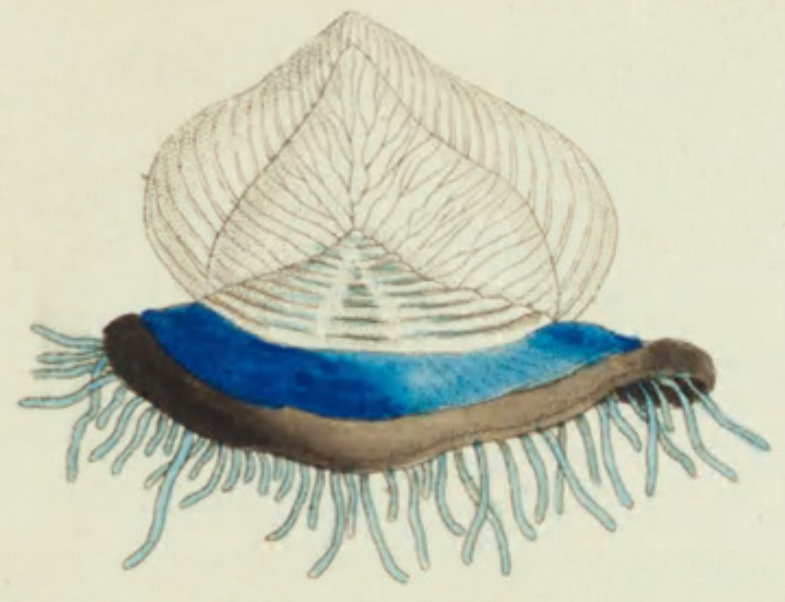

L

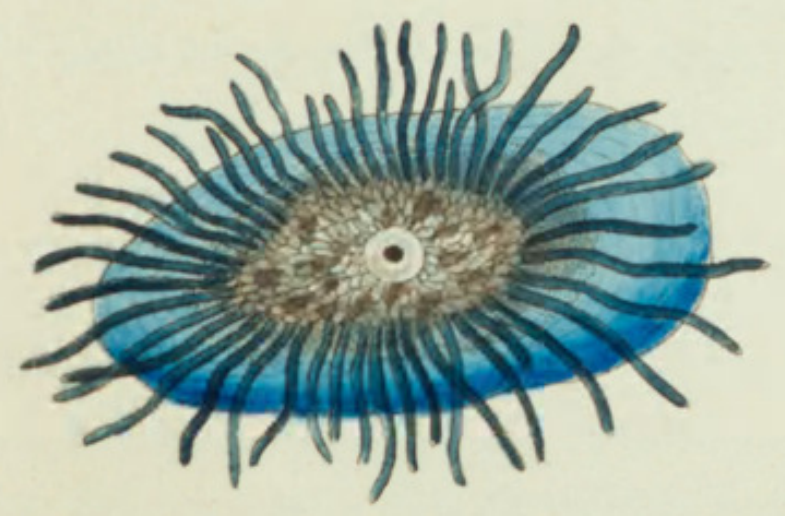




\section{$2 \mathrm{BHL}$ Biodiversity Heritage Library}

Shaw, George. 1796. "The Skiff Medusa, Medusa navicula [PI. 247]." The Naturalist's Miscellany 7(LXXXII), https://doi.org/10.5962/p.310790.

View This Item Online: https://www.biodiversitylibrary.org/item/276356

DOI: https://doi.org/10.5962/p.310790

Permalink: https://www.biodiversitylibrary.org/partpdf/310790

\section{Holding Institution}

Museums Victoria

\section{Sponsored by}

Atlas of Living Australia

\section{Copyright \& Reuse}

Copyright Status: Public domain. The BHL considers that this work is no longer under copyright protection.

This document was created from content at the Biodiversity Heritage Library, the world's largest open access digital library for biodiversity literature and archives. Visit BHL at https://www.biodiversitylibrary.org. 